HStud 24 (2010) 1, 127-134

DOI: 10.1556/HStud.24.2010.1.6

\title{
READING THE PLAINS AND THE LAKE: LANDSCAPE IN HUNGARIAN TRAVEL LITERATURE
}

\author{
PETER NEMES \\ Indiana University, Bloomington, IN \\ American Public University System \\ USA
}

\begin{abstract}
Travel writing has enjoyed continuous success since the Renaissance, and has been an important factor in shaping perceptions of individual and group identities. Especially during the second half of the eighteenth century and throughout the nineteenth century travelogues constituted an influential part of the discourse on culture, and helped, through their descriptions of the foreign and a reaffirmation of what is "us", establish the ideology of nationalism. Works by British authors such as William Wordsworth and the travel writings of Hungarian poet Sándor Petőfi and politician, essayist, and novelist József Eötvös offer examples of different strategies of using landscape as means of affirming contours of national identity.
\end{abstract}

Keywords: travel writing, landscape, regionalism, cultural travel

Human engagement with the surrounding world, originally at least, is deeply rooted in our primary senses, and as we hang on to this notion of a primordial relationship with the environment we tend to forget that the nature we are experiencing and communicating nowadays is in fact (and for a considerable time has been) a cultural product and our relationship with the environment is based on codes and expectations handed down to us through a long line of cultural transmission. The literary accounts commonly grouped under the umbrella term "travel literature" represent an important part of this transmission process. They are relatively simple narratives that follow a spatial outline, a route, and tell tales of journeys. On the surface, travel narratives serve a double purpose: they record events in the life of the traveler, forming autobiographical building blocks, and they also provide much-needed information for both the fellow traveler and those who stay at home, but remain curious, i.e., the reading public. They are also part of an ecologically oriented discourse: description, assessment and interpretation of the sites visited contribute to the understanding of place that remains one of the foremost goals of a broadly conceived ecological inquiry. Of course, travel writing is first and foremost a kind of literature, a genre that has its own history and theory, its historical periods of ascension, when it was one of the most common forms of literary pro- 
duction, along with periods when its popularity diminished, all the way up to the present day, when as a genre it has almost vanished. It is safe to say that the kind of travel writing we discuss in academic settings is a thing of the past, although not because there is no interest in what it does, but because technology has changed radically and there is no reason, assuming financial resources are available, not to produce something similar either as a documentary for television channels specializing in travel or, if resources are limited, as a travel blog. And of course, all modern guidebooks are descendents of tour books, so in an altered format and without the heavy cultural ballast travel writing is alive and well, and, along with cookbooks, constitutes one of the backbones of commercial publishing.

The success of travel narratives is easily explained by pointing out that they satisfy two very strong human drives: curiosity and storytelling. This would place travel literature in the proximity of the novel, the most successful narrative form in Western literature. In fact, it is possible to argue that travel writing, with its clear and simple basic structure of departure, travel and arrival, is a sort of elementary blueprint for storytelling within the category of longer prose. The novel has had a long and varied history, and has undergone transformations at various levels, but Robinson Crusoe, Don Quixote, Gulliver's Travels or A Sentimental Journey Through France and Italy (to name four of the most famous novels in the Western tradition) all show parallels with travel writing. On a more philosophical level travel can be considered an epistemological metaphor for the acquisition of knowledge, and can also serve as a model for human life in general, which is itself often described as a journey. So there are plenty of good reasons for the popularity and the sheer volume of travel writing produced in Europe since the Renaissance. As a genre, it caters to a basic need for storytelling and learning, while (and this, of course, should not be forgotten) also fulfilling a practical role, one that in today's world has largely been replaced by magazines, TV programs and, most notably, the internet.

Travel literature as a genre rests on a few presumptions, and although the theoretical literature regarding what constitutes the genre is relatively short and is usually buried under and among historical considerations there are a few factors that are accepted as common. ${ }^{1}$ Travelogues describe a person's journey, recount an actual, real event, are written by the person traveling, and are usually, although not necessarily, written in the first person. These essential features then lead to a number of specific characteristics, which, in turn, should guide the investigation of travel literature by asking the right questions. At the heart of all this is the relationship of the traveling individual to the outside world, to the subject that is studied, described and reconstructed in the context of the narrative. The most common form of travel is a journey away from home, away from what is well-known and customary, in other words away from the familiar. This puts the traveler into a vulnerable but at the same time exciting position. The journey is a challenge that 
forces the traveler to confront what he knows about himself or herself and about the world, while also adapting to a changing situation. On a psychological level a travel narrative engages the reader because it involves shifts in how humans construct their identity, how the Self is built and tested through its encounters with the Other. The pattern of identity construction, subtle seismic shifts of the land on which they travel, and reconstruction is usually a part of the accounts of traveling individuals, even if it is not brought to the forefront. As we all know from experience, traveling with others can build very strong bonds, and I would argue that this is the side effect of the heightened psychological state that travel so often involves.

In addition to the considerable role travel can play in the development of an individual's character, it has also lasting effects on the communities of both travelers and hosts. It is through interaction that communities develop a sense of unity and devise strategies to deal with those who are not part of their group, something that humans can do both strikingly well and strikingly badly. And it is through interaction with members of different linguistic, religious and cultural groups that group identities are developed and enforced. But just as human identities are not fixed, so do group identities undergo shift and change, the processes of which are highly visible in the history of travel narratives. It is no wonder, then, that the high point of travel writing coincides with the period of emerging nationalism, with the formation of what have famously been dubbed "imagined communities". ${ }^{2}$ Travelogues explore the habits of other nations, describe customs, point out the familiar and the strange, while at the same time encouraging members of the reading community to develop a stronger sense of who they are. The description and construction of national character is a central concern of travel writing, especially in the nineteenth century, and it unfolds in both settings: domestically and abroad. Being abroad helped British authors on the Grand Tour, for example, to determine what made the British different from their neighbors on the continent, while domestic travel was preoccupied with the question of what made the British who they were (or, at the very least, who they portrayed themselves to be). Later on we shall see how Hungarian poet Sándor Petőfi consciously built a unique Hungarian sense of place in his travel writings, with a focal point that is deliberately different from that encountered in most European travelogues. But first we should take a look at a chapter in the history of English travel writing in order to have a sense of comparison with the later Hungarian examples.

Alongside the rich travel narratives of 18th century English literature recounting journeys abroad (notable examples include William Dampier's A New Voyage Round the World,1697; Henry Fielding's Journal of a Voyage to Lisbon, 1755; James Boswell's Account of Corsica, 1768; and Mungo Park's Travels in the Interior Districts of Africa, 1799), one finds an ever increasing number of literary works narrating experiences of domestic travel and explorations of the British 
Isles. And while Scotland was quite remote from London, a journey to Edinborough, for example, still meant exploration of the local or semi-local, furthering the ability to develop a better sense of community. In Thomas Gray's famous account, Journal in the Lakes (1775) and its most famous sequel, William Wordsworth's Guide to the Lakes (1835), attention is turned towards Cumbria, a relatively small region in the northwest of Britain with a distinctive landscape of small lakes. The change of focus was partially historical or political. Travel in Europe had become more perilous around the turn of the century and in the first decades of the nineteenth century, and relationships between England and France were strained. But it was also, to a great extent, an expression of an evolving British national identity, a discourse that centered around English singularity or originality. This, of course, coincides with a gradually growing middle-class, the primary vehicle of nationalism in all of Europe. This continuously developing reading public was simply more interested in buying individual accounts of travels that also provided them with practical information (Wordsworth's Guide, for example, has an itinerary that lists the walking distances between the lakes and the inns and public houses along the way) than in investing in pricey volumes of accounts describing travels around the world that had primarily a scientific purpose and strove only secondarily to entertain.

One should keep in mind that this shift took place at the end or soon after the long 18th century, when the British had had time to refine the art of continental travel through the obligatory Grand Tour. ${ }^{3}$ This institutionalized form of cultural travel helped to establish the travel narrative as one of the most common literary genres, and, more importantly, it instilled a strong sensitivity towards the experience of landscape. Ultimately it lead to the development of picturesque aesthetics, which constituted a complex mixture of visual references, philosophical ideas and an interest in "enhancements", the eighteenth century expression for garden or estate redesign. The picturesque is not simply the transitional period between the aesthetics of Sentimentalism and Romanticism. It is also the aesthetic mother tongue of Romantic poets, who were born at the start of the picturesque movement. It is impossible to understand the Romantic landscape poem without an understanding of picturesque concepts. The first major picturesque author, the Reverend William Gilpin, offers as pertinent an introduction to Wordsworth as does Milton. Gilpin should also be mentioned for his series of Observations (influential domestic travelogues that started the aesthetic discourse of the picturesque), since their constant concern is the proper appreciation of landscape: how to look at a site in order to maximize the value of the experience and how to find the best sites over the course of an excursion. This entails an objectification of the visual components of the location, which leads to the formalized visual rhetoric of the picturesque (which, as its critics are keen to point out, can soon become mechanical), but it also helps to crystallize the view according to which landscape is a vehicle 
for human expression, and nature a huge canvas for illustrations. The next step is the Romantic landscape poem, in which the natural environment functions as an outward representation of the rapidly inflating Self. Wordsworth's The Prelude is an autobiographical mega-poem, while it is also, in great part, a poem on landscape. The growth of a poet's mind is repeatedly associated with places in nature. These places carry the ballast of meaning and serve as mnemonic devices, since they help to reconstruct (or rather construct within the poetic realm of the poem) whatever can be reconstructed from a former Self. What is particularly pertinent in the context of the present discussion is the concept or rather the possibility of mental constructions through the evocation of landscapes or elements of landscape. This is something that we should be able to observe in the travel writings of Petôfi, although in a different context and with a different purpose.

Hungarian literary history usually tells a tale of belatedness, adaptation and transformation that is further complicated by the experience of linguistic isolation. As members of the periphery of European cultural production, Hungarian authors typically exhibit a mixture of longing and singularity: a longing to adopt the practices of the cultural center and a strong sense of singularity, a uniqueness that can't be properly understood from the outside. The question of cultural and national identity and the construction of a national image are recurring questions for Hungarian intellectuals. In the 18th century there emerged a strong need to explain what Hungary and the Hungarians were. Travel literature seemed to be a good medium in which to ponder these questions, and as a result travel literature written in Hungarian is fairly close to the European standard of production in this genre. The volume of travel accounts is of course relatively low, but the genre was easily integrated into Hungarian literary discourse, from the 1620 publication of Márton Szepsi Csombor's Europica varietas all the way to the travel diaries of István Széchenyi and beyond. A few examples of the genre are travelogues describing the Hungarian search for the nation's origins and other ventures Eastward, into the past, such as the journey of Antal Reguly, which lead to the first ethnographic description of the Mansi people. Others are travelogues focusing on journeys through Europe, such as the diaries of Miklós Wesselényi or the account of József Irinyi. Finally there were also accounts of domestic travel that promote self-reflection. (It is worth mentioning as a side note that the famous journey of Sándor Körösi Csoma, of which there is sadly no first-hand account, ended not with the discovery of the birthplace of the Hungarian nation, but the founding of Tibetology.) Geographical space is temporalised in these travel narratives on an east/west axis. To the east lies the semi-mythical past, while to the west the traveler can find the future. ${ }^{4}$ Széchenyi's primary concern during his trip to Britain was to learn about improvements in engineering, the development of public space, and transportation technologies that might offer the promise of a better future for his country. So, while the conditions of the travel experience were undeniably 
worse (for many foreign travelers Hungary was too far, and perhaps even less safe than other European destinations, the roads were often quite bad, and the coach service was underdeveloped), the description of travel was in many ways similar to that of the rest of Europe.

How do Sándor Petőfi's travel writings, the Úti jegyzetek (Travel Notes) and the Úti levelek Kerényi Frigyeshez (Travel Letters to Frigyes Kerényi), fit into this genre ${ }^{5}$ They were written immediately after his trips to Upper and Eastern Hungary and Transylvania in 1845 and 1847 and record with considerable autobiographical precision important moments in the life of the young (he was 22 years old in 1845), highly successful, controversial and popular poet. (It is worth noting that Petófi was the first Hungarian poet to attempt to make a living entirely from writing.) The letters are fictitious, and from the beginning were written for publication, a common literary format at the time. These writings mark a strong departure from the literary norm of their day in their tone and style. Petőfi didn't just present a fresh voice; he was quite radical in his direct and bold manner of addressing the reader and using a colloquial tone throughout his travel accounts. In the case of Úti levelek, the epistolary structure helps considerably. A private letter to a good friend might employ a less formal style, but these writings were never intended for anybody other than the curious reading public. The first-person narrative, which addresses the reader directly, breaks with the conventional distance between writer and reader, though the real novelty of Petöfi's travel writings lies in their primary objective of building the private mythology of the poet, something we might now call a public relations campaign. Petôfi understood the power of celebrity, both as a financial tool and as a means of changing aesthetic perceptions. So his travel accounts are first and foremost about the public persona he is promoting; the question of landscape is only secondary. However, once one considers the question of landscape in these writings, one sees a conscious and concentrated effort to alter the common association of sublimity with mountains (the higher, the better) and portray the flat Alföld (the low-lying Hungarian plain) as the most Hungarian of all landscapes. If viewed from the perspective of a picturesque sensibility, the plains lack visual interest, since there is no ruggedness, no juxtaposition, no texture, only perfectly flat grassland. Petófi was well aware of this and still claims the plains as the center of Hungarian spatial consciousness, a status it has basically retained ever since. In terms of cultural geography an excursion to Hortobágy is a visit to the center of Hungarianness, for foreign and domestic tourists alike. Petőfi was consciously building a group identity out of spatial metaphors that run counter to the aesthetic norm, are easily identifiable and clearly different from the descriptions of the Alps given by English tourists of the Grand Tour. He maintains his admiration for the puszta (plains) throughout his Notes and Letters, and often attacks mountain-mythology directly, although at certain Transylvanian locations during his second trip (Nyirestető, for example) 
he tends to forget his mission and expresses his admiration for higher geological formations. In summary, in his travel writings Petôfi is engaged in creating mythologies on two distinct levels: one for a heightened sense of Self that explicitly proclaims himself as the center of the universe and filters all events and reflections of an emotionally charged and anthropomorphic landscape for the purpose of building a private mythology (mostly centered around his beloved and his recent marriage), and another at the level of national identity, as reflected in the native landscape.

A different kind of travel writing emerges at the end of the 19th century in the work of the noted lawyer and journalist, Károly Eötvös, who was famous for having successfully defended the Jews accused in the 1882-83 Tiszaeszlár blood libel, a highly publicized event in Hungarian legal history. On the surface, his Balatoni utazás (Journey around Balaton) and A balatoni utazás vége (The End of the Journey around Balaton $)^{6}$ are accounts of former travels around his native region, and might suggest comparisons with the tradition of guidebooks to the Lake region in Britain. However, it is soon apparent that his accounts are quite different. They are written in a different style and serve a different purpose. Eötvös is a true regionalist, with an extensive knowledge of local lore, but his real interest is in the preservation of a bygone period. In his work the geographical locations are given only brief discussion. They serve more as backdrops for countless stories of people representative of the region and, most importantly, of a romanticized past. The obvious explanation for this preservationist drive would be the sense that the culture and traditions of 19th century Hungary were swiftly vanishing (the turn of the century was undoubtedly one of the most socially active periods in Hungarian history, a period that bore witness to an unprecedented wave of developments). In order to rescue both the common and the extraordinary and memorialize typical figures and famous events, Eötvös employs a narrative technique that was in itself something of an anachronism: the anecdote. The anecdote is essentially an oral form that partially depends on voice, intonation and timing, in short on the delivery of the story, and if translated into writing it works best in short literary formats, such as short stories. Despite this, it has become an important structural element in Hungarian literature, and has influenced writers from Mór Jókai to Péter Esterházy, especially Kálmán Mikszáth and Gyula Krúdy. Eötvös integrates it into travel literature, producing a written journey that tells less about the environment and more about the habits and customs of the people once inhabiting the landscape. His admiration for Lake Balaton and its beauties is evident throughout, yet unlike in the case of Wordsworth, for instance, his landscape is not so much a geographical location to be explored and described, not so much a vehicle for defining identity or the object of an aesthetically guided reflection with the possibility of reconstructing a former Self, as it is a backdrop for storytelling. 
Both the plains of Petöfi and the lake of Eötvös have become central in the spatial identity of Hungarian culture. They function not simply as two of several regions. This is not necessarily because of the works of these authors (although in the case of Petőfi it is possible to argue that his work had a determinative influence), but it is clear that literary accounts, along with visual representations, are able to determine or to alter the image of a region and contribute to the shaping of a national identity as it is expressed through place. The examples of Wordsworth, Petőfi and Eötvös illustrate that landscape can serve different roles in national literary canons, with very different outcomes, but in each instance landscape is far more than just setting. It figures as one of the main characters of narrative, and should be considered as such.

The liber mundi, the metaphor of the world as a book that is waiting to be read, is part of the Judeo-Christian tradition (with its famous expression in the opening verses of the gospel of John), and it has been interpreted in various ways, but for members of the literary profession it serves as a sort of assertion that their profession is of special value. If textual interpretation is understood as an endeavor that offers to reveal more than simply the contents of books, the hermeneutics of the literary historian acquires particular importance. There might also be a very literal application of the liber mundi. We should read the world and the environment as they appear in texts, while also reading (that is interpreting) the ways in which texts within a tradition have shaped our understanding of place.

\section{Notes}

For example see: Korte, Barbara (2000) English Travel Writing from Pilgrimage to Postcolonial Explorations (New York: Macmillan); Chard, Chloe (1999) Pleasure and Guilt on the Grand Tour: Travel Writing and Imaginative Geography 1600-1830 (Manchester-New York: Manchester University Press), and Viviès, Jean (2002) English Travel Narratives in the Eighteenth Century: Exploring Genres (Aldershot: Ashgate).

For a specifically Eastern European perspective see Bracewell, Wendy and Alex Drace-Francis (Eds) (2008) Under Eastern Eyes: A Comparative Introduction to East European Travel Writing on Europe (Budapest: Central European University Press).

2 See Anderson, Benedict (1991) Imagined Communities: Reflections on the Origin and Spread of Nationalism (London: Verso).

3 For details see Chard's Pleasure and Guilt on the Grand Tour.

4 See Irina V. Popova-Nowak 'The Odyssey of National Discovery: Hungarians in Hungary and Abroad, 1750-1850' in Bracewell, Wendy and Alex Drace-Francis (eds) Under Eastern Eyes.

5 Both can be read through the Hungarian Electronic Library (Magyar Elektronikus Könyvtár): http://mek.niif.hu/06100/06125/html/index.htm

6 These are commonly printed together. The last edition is from 1982, in the Magyar Hirmondó series of the Magvető publishing house, edited by Károly Szalay. 